\title{
Effectiveness of magnesium oxide additives in mitigating fouling problems in kraft recovery boilers
}

\author{
LIMING ZHAO, HONGHI TRAN, AND F. DONALD MCCABE
}

\begin{abstract}
A systematic study was performed in the laboratory and in the field to examine the effect of magnesium oxide additive on deposit accumulation and removal. Laboratory results show that the additive has little effect on the amount of deposits collected on a probe, but it can make deposits easy to remove if a coating layer thicker than $30 \mu \mathrm{m}$ can be effectively applied on the probe surface. The results also show that mixing the additive with black liquor or injecting it separately has no significant effect on deposit accumulation and removal. Tests performed in a recovery boiler where the additive was continuously injected show no evidence for the existence of the coating layer. The magnesium oxide content in the boiler deposits varied between 0.1 and $0.4 \mathrm{wt} \%$, which is several times lower than the amount that was found to be effective in laboratory tests. Nonetheless, the additive was shown to be effective in facilitating deposit removal if it can form a coating layer on deposit/tube surfaces. This may be possible by periodically injecting a large amount of additive into the boiler for a short period and reducing the black liquor firing rate at the same time.
\end{abstract}

Application: Mills may use this information to assess whether it is worthwhile to use magnesium oxide additives for controlling fireside fouling in recovery boilers.

$\mathbf{F}$ ouling of heat transfer tube surfaces by fireside deposits is a persistent problem in many kraft recovery boilers. Deposits decrease the boiler heat transfer efficiency; create a corrosive environment at the tube surface; and in severe cases, completely block flue gas passages, leading to unscheduled boiler shutdowns for deposit removal.

Effective control of deposit accumulation is of vital importance in recovery boiler operation and is conventionally attained by means of a sootblower, which knocks the deposits off from the tube surface with high-pressure steam jets. In oil- and coal-fired boilers and boilers that burn high-alkalicontaining fuels, fireside additives are often used, along with sootblowers, to control fouling and corrosion $[1,2]$. Additives are commonly mixtures of oxides with high melting temperatures, such as magnesium oxide $(\mathrm{MgO})$, calcium oxide $(\mathrm{CaO})$, silicon dioxide $\left(\mathrm{SiO}_{2}\right)$, and aluminum oxide $\left(\mathrm{Al}_{2} \mathrm{O}_{3}\right)$. Minerals such as calcite $\left(\mathrm{CaCO}_{3}\right)$, magnesite $\left(\mathrm{MgCO}_{3}\right)$, dolomite $\left(\mathrm{CaMg}\left(\mathrm{CO}_{3}\right)_{2}\right)$, brucite $\left(\mathrm{Mg}(\mathrm{OH})_{2}\right)$, and kaolinite $\left(\mathrm{Al}_{2} \mathrm{Si}_{2} \mathrm{O}_{5}(\mathrm{OH})_{4}\right)$ have also been used [2]. Of these, MgO-based additives (i.e., $\mathrm{MgO}, \mathrm{Mg}(\mathrm{OH})_{2}$, and $\mathrm{MgCO}_{3}$ ) are considered to be the most effective because of the high melting temperature, high alkalinity, and low chemical reactivity of $\mathrm{MgO}$.

While less common, $\mathrm{MgO}$ additives have also been used in a number of recovery boilers to prolong the boiler operating time between washouts [3-5]. The additives are typically injected into the boiler at a location above the tertiary air level, where they are entrained in the flue gas to the upper furnace. They are said to work by forming a thin, loosely bonded layer of $\mathrm{MgO}$ coating on the tube surface, which either prevents deposits from building up and/or makes deposits easy to remove by sootblowers. Experience varies widely from mill to mill. Some boiler operators believe that the use of $\mathrm{MgO}$ additive has helped to alleviate their fouling problem, while others are more skeptical of such benefits.

The effectiveness of the practice has not been scientifically proven. In the late 1990s, Tran [5] conducted a study using an air-cooled probe coated with a layer of $\mathrm{Mg}(\mathrm{OH})_{2}$ and exposed it in an overloaded recovery boiler at the boiler bank inlet for $1.5 \mathrm{~h}$. He found that the additive coating was effective in minimizing deposit accumulation only when it was thick $(<1 \mathrm{~mm})$, and it was not effective at all when it was thin $(<0.2 \mathrm{~mm})$. He concluded that for an additive treatment to work in a recovery boiler, a large amount of additive is needed to cover the tube surface. Tran's study, however, did not examine the effectiveness of additive treatment on deposit removability by sootblower jets.

It is difficult to perform a well-controlled study in an operating recovery boiler because of the hostile environment and the high variability of boiler operating conditions. The availability of an entrained flow reactor (EFR) and a deposit removal apparatus in our laboratory at the University of Toronto (Fig. 1) makes it possible to simulate both deposit formation and removal processes in recovery boilers with and without additive treatment.

This paper summarizes the main findings of Liming Zhao 


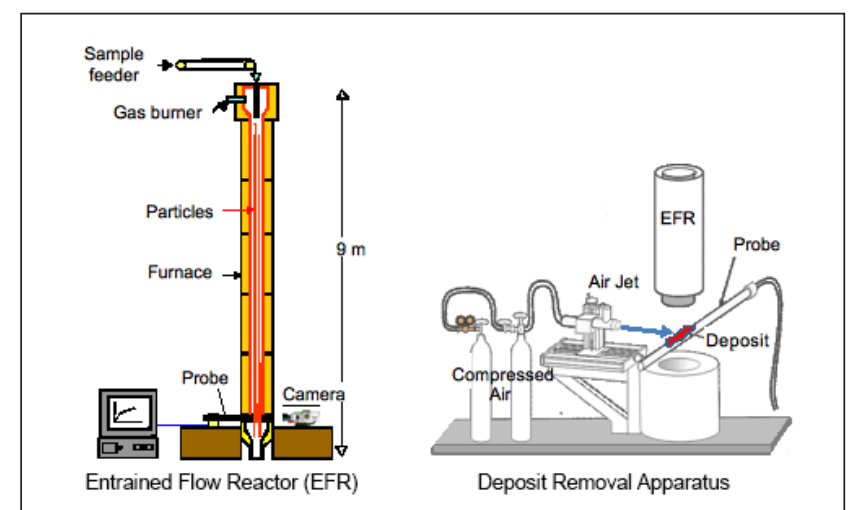

1. Entrained flow reactor and deposit removal apparatus.

in her master's thesis study [6]. The objectives of the study were to investigate (1) how thick a coating layer would be needed for an $\mathrm{MgO}$ additive treatment to be effective in minimizing deposit buildup, both in terms of deposit formation and removability and (2) whether such a coating layer could be formed on a tube surface in the recovery boiler. The study involved a series of laboratory experiments at the university and a field test in an operating recovery boiler.

\section{LABORATORY EXPERIMENTS}

\section{Materials}

Two types of additives were examined in this study. One was pure, analytical-grade $\mathrm{Mg}(\mathrm{OH})_{2}$ powder and the other was a commercial additive, which consisted of mainly slurry of $\mathrm{Mg}(\mathrm{OH})_{2}$ powder obtained from a kraft mill. Both additives were completely dried in an oven at $110^{\circ} \mathrm{C}$. Table I shows the $\mathrm{Mg}(\mathrm{OH})_{2}$ content and the decomposition temperature of the dried materials determined using a thermogravimetric analysis/differential scanning calorimetry analyzer.

The black liquor sample used in this study was as-fired black liquor with a solids content of $73 \mathrm{wt} \%$. The sample was obtained from the same kraft mill where the commercial additive was used.

Synthetic carryover particles, 90-300 $\mu \mathrm{m}$, were prepared by melting, cooling, grinding, and sieving a mixture of analytical-grade chemicals (sodium sulfate $\left[\mathrm{Na}_{2} \mathrm{SO}_{4}\right]$, sodium carbonate $\left[\mathrm{Na}_{2} \mathrm{CO}_{3}\right]$, and sodium chloride $\left.[\mathrm{NaCl}]\right)$ with a chlorine (Cl) content of $10.5 \mathrm{~mol} \% \mathrm{Cl} /(\mathrm{Na}+\mathrm{K})$. The high $\mathrm{Cl}$ content used in this study was to ensure that the carryover particles

\begin{tabular}{|l|c|c|}
\hline & $\begin{array}{c}\text { Pure } \\
\text { Chemical }\end{array}$ & $\begin{array}{c}\text { Commercial } \\
\text { Additive }\end{array}$ \\
\hline $\mathrm{Mg}(\mathrm{OH})_{2}, \mathrm{wt} \%$ & 98.3 & 96.5 \\
\hline Other, wt\% & 1.7 & 3.5 \\
\hline $\begin{array}{l}\text { Decomposition } \\
\text { temperature, }{ }^{\circ} \mathrm{C}\end{array}$ & 350 & 350 \\
\hline
\end{tabular}

I. $\mathrm{Mg}(\mathrm{OH})_{2}$ content and decomposition temperature of additives used. would be sufficiently sticky so that they would deposit on the probe surface at the exit of the EFR upon impact.

\section{Experimental setup}

Experiments were performed using the EFR and the deposit removal apparatus (Fig. 1). Synthetic carryover particles or dried black liquor particles mixed with various amounts of additive were introduced continuously into the top of the EFR via a belt feeder at a rate of $5 \mathrm{~g} / \mathrm{min}$. An air-cooled, $1.6-\mathrm{cm}$ (3/4-in.) outside diameter (OD) 304 stainless-steel probe was placed horizontally at the EFR exit to collect particles falling from above. The probe was connected directly to a magnetic weight cell to measure the amount of deposits accumulated on its surface. The EFR temperature was controlled at $800^{\circ} \mathrm{C}$ while the probe surface temperature was at $470^{\circ} \mathrm{C}$. The gas velocity and the average particle velocity at the exit were estimated to be about $1.8 \mathrm{~m} / \mathrm{s}$ and $2 \mathrm{~m} / \mathrm{s}$, respectively. A data acquisition system was used to continuously record the gas temperature and flow rate, furnace temperatures, probe surface temperature, and deposit weight.

To determine the removability of the accumulated deposit after each test, the probe was turned to make the deposit directly face an air jet, which was produced by passing compressed air at $300 \mathrm{psig}$ pressure through a nozzle with a throat diameter of $4.7 \mathrm{~mm}$ and an exit diameter of $9.2 \mathrm{~mm}$. The peak impact pressure (PIP) of the jet was increased by moving the nozzle closer to the deposit until a sign of deposit removal was observed. The PIP value at that point was considered to be the minimum PIP required to remove the deposit. It was calculated using a correlation previously determined between the PIP and the distance from the nozzle exit with a pitot tube. Details of the EFR, the deposit removal apparatus, and their operating procedures have been previously described $[7,8]$.

Three additive application methods were employed in this study to simulate operating conditions in recovery boilers:

1. Surface coating (coating the probe surface with a layer of additive before exposing the probe to the EFR). This method was used to examine the validity of the common claim that $\mathrm{MgO}$ additive works by forming a loosely bonded layer of coating on the tube surface, which either prevents deposits from building up and/or makes deposits easy to remove by sootblowers.

2. Mixed injection (mixing the additive with black liquor and burning the mixture in the EFR). This method was used to examine the effectiveness of the additive when it is well mixed with black liquor. The rationale is that once injected into a recovery boiler, only a small portion of the additive is expected to be embedded in deposits in the upper furnace. The majority would follow the flue gas, be captured by electrostatic precipitators and ash hoppers along with other fly ash components, and eventually becomes part of the as-fired black liquor burned in the boiler.

3. Separate injection (feeding the additive and black liquor 


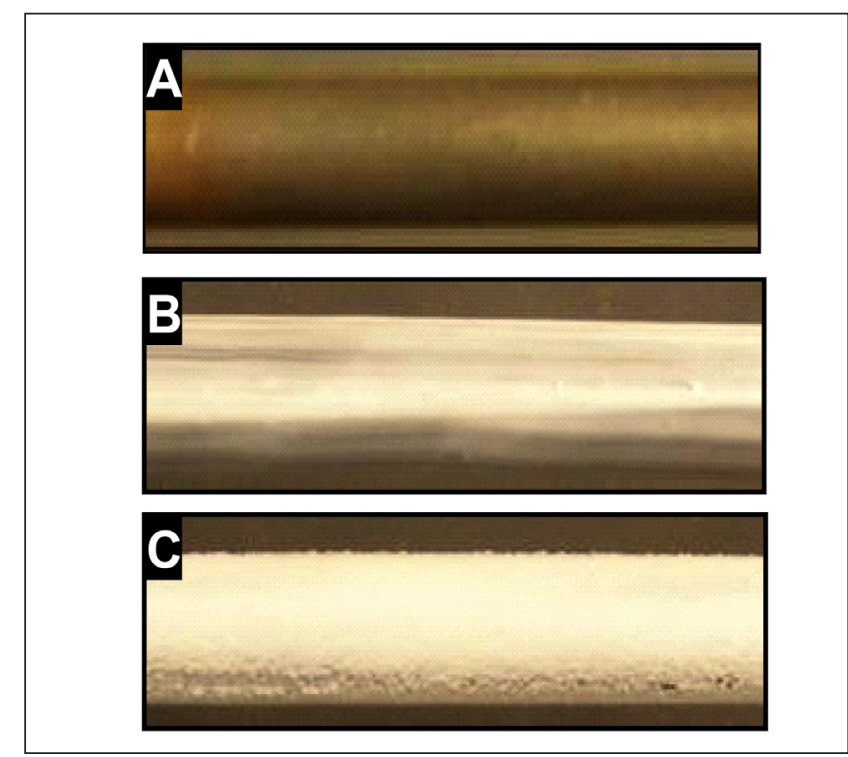

\section{Probe surface: (a) uncoated, (b) coated with a layer of $\mathrm{Mg}(\mathrm{OH})_{2}$ before test, and (c) after test.}

separately into the EFR). This method was to examine the effectiveness of the additive when the additive and the black liquor are introduced separately into the boiler. This is the most common additive feeding method. The rationale is that by injecting the additive at a location high up in the boiler (i.e., the tertiary air level or higher), the additive would uniformly disperse and follow the flue gas, forming a thin layer of inert material on the tube and existing deposit surfaces. This thin coating, similar to the case described in the surface coating method, may help prevent deposits from building up and/or make deposits easy to remove by sootblowers.

Experimental procedures and results for each application method are discussed in the following sections.

\section{Additive coating}

As illustrated in Fig. 2, the probe surface was first painted with a slurry of additive and water using a brush and then dried in air. The coating thickness was varied by changing the slurry concentration and/or by applying the coating several times. Because the probe surface was at a much higher temperature than the decomposition temperature of $\mathrm{Mg}(\mathrm{OH})_{2}$, the coating layer was rapidly converted into $\mathrm{MgO}$ as the probe was exposed to the hot gas at the EFR exit. The thickness of the $\mathrm{MgO}$ coating was calculated based on the amount of $\mathrm{MgO}$ contained in the coating layer, the coated surface area, and the bulk density of dried $\mathrm{MgO}$ powder, $0.8 \mathrm{~g} / \mathrm{cm}^{3}$.

In this series of experiments, only synthetic carryover particles were used. Figure 3 shows the amount of deposits accumulated on the probe surface at the end of each test as a function of $\mathrm{MgO}$ coating thickness for both pure and commercial additives. In all cases, the amount of deposits collected after each test was about $1.2 \mathrm{mg} / \mathrm{cm}^{2} / \mathrm{g}$ of synthetic

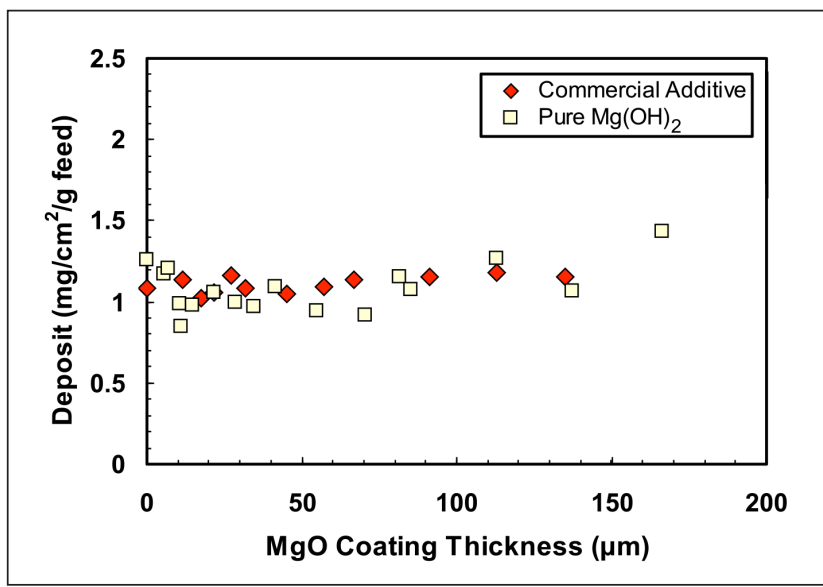

3. Effect of additive coating thickness on deposit accumulation.

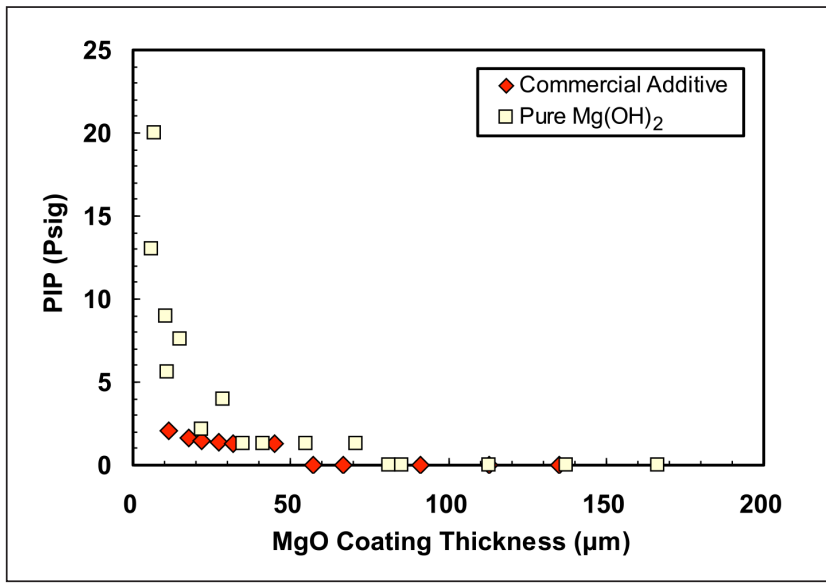

4. Effect of additive coating thickness on deposit removal.

carryover particles fed into the EFR. No significant change in the amount of deposits accumulated on the probe with coating thickness was observed for both pure and commercial additives.

The effect of additive coating thickness on deposit removal, however, was quite different, as shown in Fig. 4 . With a thin coating (about $5 \mu \mathrm{m}$ ), the PIP of the air jet required to remove the deposit from the probe surface was more than 15 psig. It decreased drastically to about 2 psig as the coating thickness was increased to about $30 \mu \mathrm{m}$. At $80 \mu \mathrm{m}$ or thicker, the PIP was practically zero. The deposit fell off by itself when the probe was rotated to align the deposit directly against the air jet, even before the jet blow was initiated. These results clearly suggest that while the MgO additive coating has little effect on deposit buildup, it dramatically alters the bonding between the deposit and the substrate, making the deposit easy to remove.

\section{Mixed injection}

To examine the effectiveness of the additive that has been mixed with black liquor, the as-fired black liquor sample $(73 \%$ dry solids) was warmed to $90^{\circ} \mathrm{C}$ and mixed with various 


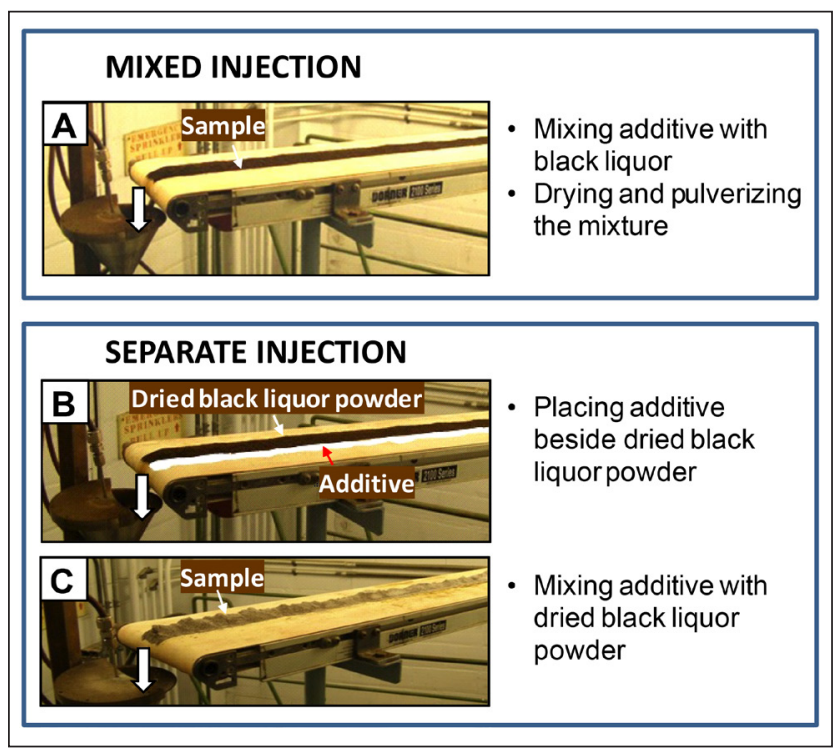

5. Sample preparation and particle feeding methods.

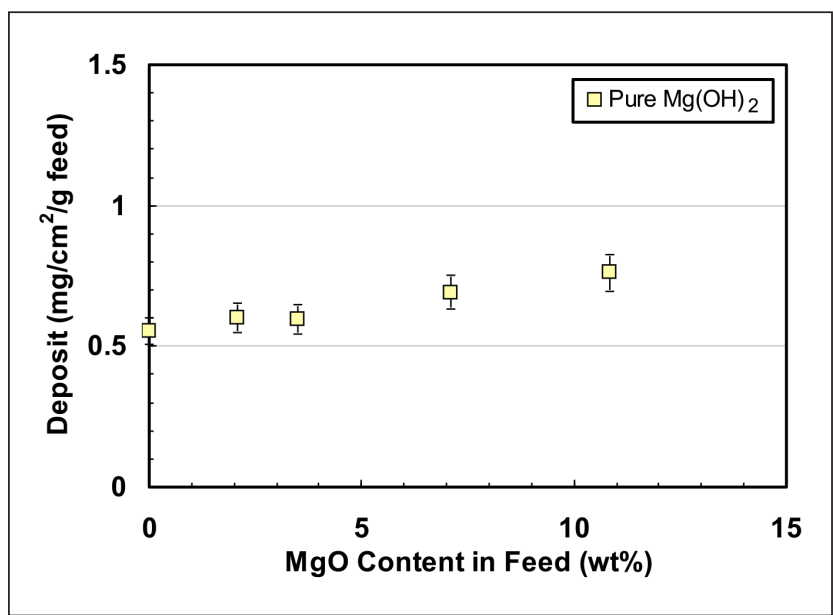

\section{Effect of $\mathrm{Mg}(\mathrm{OH})_{2}$ mixed with black liquor on the amount of} deposits collected on probe.

amounts of pure $\mathrm{Mg}(\mathrm{OH})_{2}$. The mixture was uniformly mixed and dried in an oven at $110^{\circ} \mathrm{C}$. The dried sample was ground and sieved to produce particles smaller than $600 \mu \mathrm{m}$. The particles were placed on a belt feeder at the top of the EFR, as shown in Fig. 5a. Also shown in Fig. 5b and 5c are photos of samples on the belt feeder in different sets of experiments where the additive and black liquor were introduced separately into the EFR. These will be discussed later in this paper.

The procedure for experiments using dried black liquor particles was similar to that in the surface coating case, where synthetic carryover particles were used. In this case, however, the probe surface was controlled at a lower temperature, $400^{\circ} \mathrm{C}$, to make the deposits easier to remove. The particle feed rate was fixed at $10 \mathrm{~g} / \mathrm{min}$. After each test, the deposit was scraped from the probe and its composition (mostly magnesium $[\mathrm{Mg}]$ and sodium $[\mathrm{Na}]$ ) was analyzed using X-ray fluorescence spectroscopy.

The results are shown in Fig. 6 , where the amount of

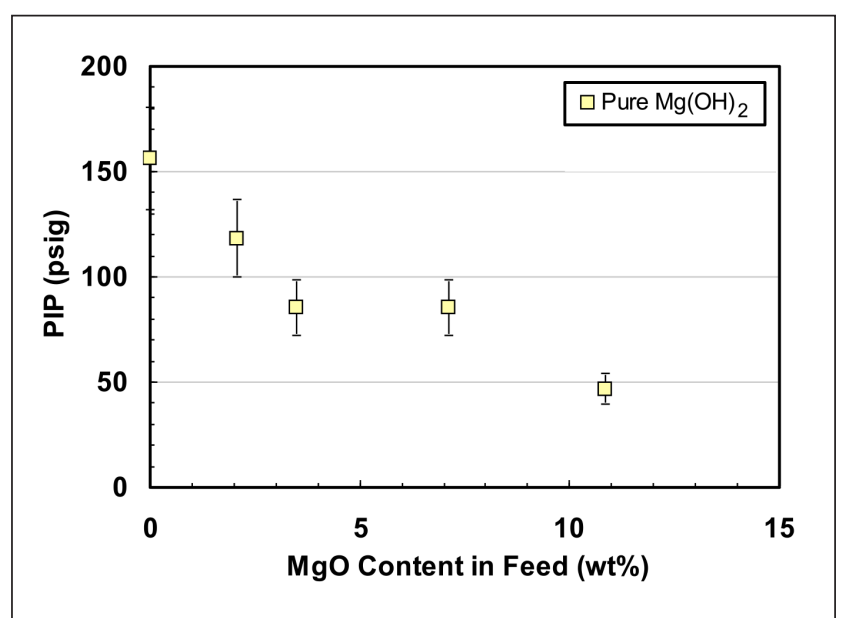

7. Effect of $\mathrm{Mg}(\mathrm{OH})_{2}$ mixed with black liquor on the removability of deposits collected on probe.

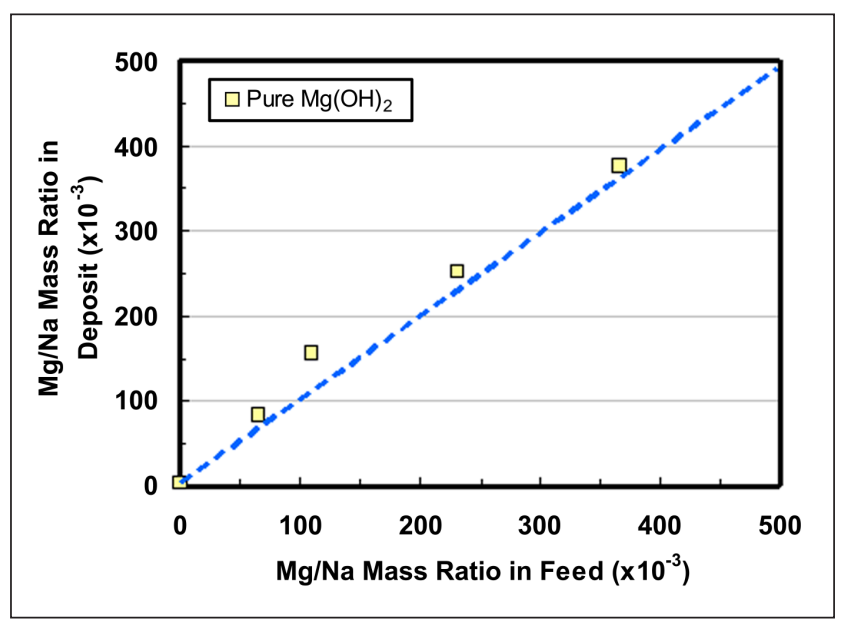

\section{Comparison of $\mathrm{Mg} / \mathrm{Na}$ mass ratios in the deposit and in black} liquor.

$\mathrm{Mg}(\mathrm{OH})_{2}$ added to the black liquor is expressed as $\mathrm{wt} \% \mathrm{MgO}$ in the feed. For the black liquor that contained no $\mathrm{Mg}(\mathrm{OH})_{2}$ or $0 \mathrm{wt} \% \mathrm{MgO}$, the amount of deposits collected on the probe surface at the EFR exit was about $0.55 \mathrm{mg} / \mathrm{cm}^{2} / \mathrm{g}$ feed. It in creased almost linearly with an increase in $\mathrm{MgO}$ content in black liquor.

Because dried black liquor particles were used in these experiments, as opposed to synthetic carryover particles in the surface coating case, deposits were much more tenacious. Because of this, the compressed air pressure at the nozzle inlet used in the deposit removal tests was increased from 300 psig to 800 psig. The results are shown in Fig. 7. The minimum PIP of the air jet needed to remove the deposit decreased with an increase in $\mathrm{MgO}$ content in black liquor. This is presumably due to the dilution effect of $\mathrm{MgO}$. Because $\mathrm{MgO}$ is thermally inert, it is solid, thereby lowering the liquid content of the burning black liquor particles (carryover particles) before they hit the probe surface. The lower liquid content would make the deposit easier to remove, as reported by Mao et al. [8]. 
Figure 8 compares the $\mathrm{Mg} / \mathrm{Na}$ mass ratio in the deposit to that in the feed. The correlation was almost 1:1. This is not surprising, because $\mathrm{Mg}(\mathrm{OH})_{2}$ was completely embedded in the black liquor and so it should also be embedded in the carryover particles that deposited on the probe surface. The correlation was consistent with the results shown in Figs. 6 and 7 that mixing $\mathrm{Mg}(\mathrm{OH})_{2}$ with black liquor increased deposition due to an increase in ash content of the black liquor as a result of $\mathrm{MgO}$ addition, but decreased the PIP required for deposit removal due to the decrease in liquid content in carryover particles as a result of the dilution effect of $\mathrm{MgO}$.

\section{Separate injection}

Two sets of experiments were performed in this study. The first set was to simulate the situation where the additive and black liquor are injected into the boiler separately from different locations. The additive (pure $\mathrm{Mg}[\mathrm{OH}]_{2}$ or commercial additive) was placed side by side with dried black liquor particles on the belt feeder as shown in Fig. 5 so that once inside the EFR, the additive particles and the black liquor particles would fall independently from one another to the bottom of the re-

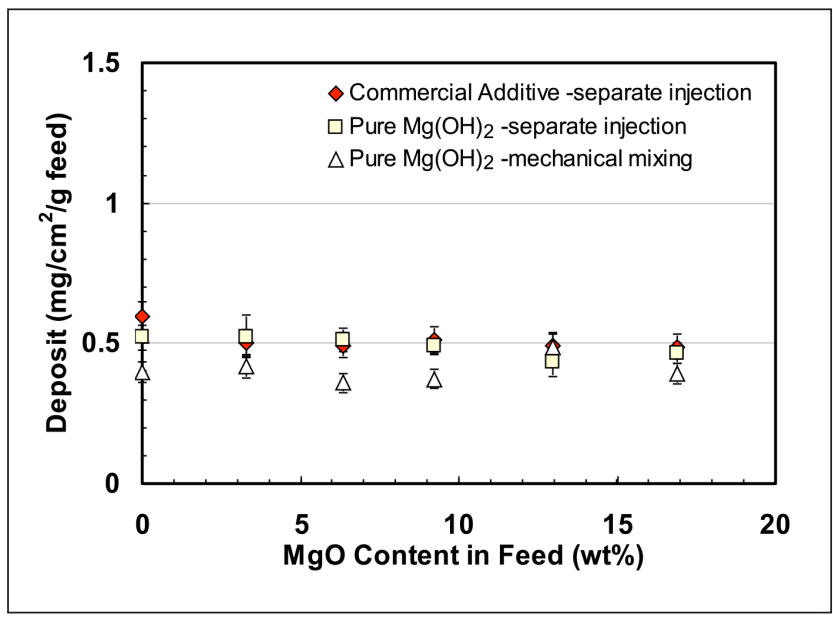

9. Effect of additives injected separately from black liquor on deposition.

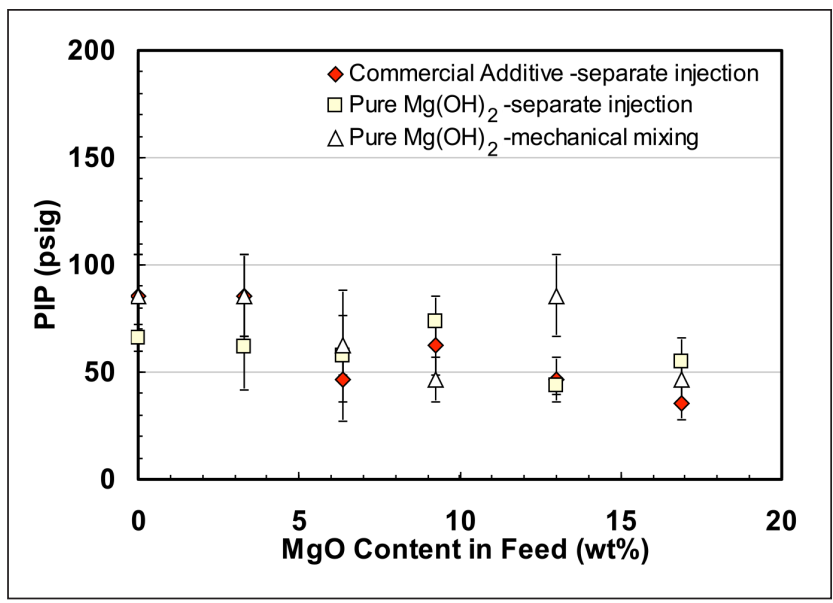

10. Effect of additives injected separately from black liquor on deposit removal.

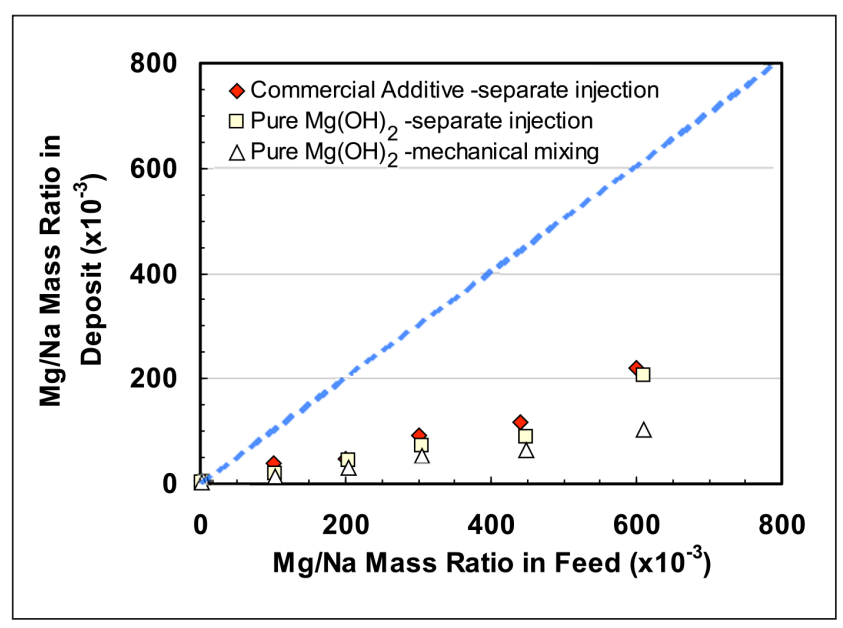

11. Comparison of $\mathrm{Mg} / \mathrm{Na}$ mass ratios in deposits and in feed obtained from separate injection experiments.

actor.

The second set of experiments was slightly different. It was to simulate a situation in the boiler where the additive particles and the black liquor carryover particles are within a very close proximity from one another before they hit the tube surface. In this case, dried black liquor particles were first mechanically well mixed with additive. The mixture was then placed on the belt feeder, as shown in Fig. 5c.

Figures 9 and 10, respectively, show the effect of the amount of additive injected with dried black liquor, expressed as $\mathrm{MgO}$ content in feed, on the amount of deposits collected on the probe (deposition), and the minimum PIP required for removing deposits from the probe surface (removal). Only a slight decrease in deposition and removal with an increase in $\mathrm{MgO}$ content was observed. The effects were virtually the same for both sets of experiments, suggesting that the $\mathrm{MgO}$ additive has little impact on deposition and removal if it and the black liquor are injected separately.

Figure 11 compares the $\mathrm{Mg} / \mathrm{Na}$ mass ratio in the deposits obtained from both sets of experiments to that in the feed. The correlation was less than 1:4, compared to 1:1 observed in the mixed-injection case where the additive was embedded in the black liquor (Fig. 8). The results suggest that if separately injected, the chance for $\mathrm{MgO}$ additive particles to deposit together with carryover particles on a tube surface is less than $25 \%$, even in the most intimate scenario where additive and carryover particles were placed close to each other.

The lower additive capture efficiency (about 25\%) in the separate-injection case compared to the mixed-injection case can be explained by the inherent difference in physical conditions of the additive particles between the two cases. As shown in Fig. 5, the colors of the samples on the belt feeder are different. The sample in Fig. $5 \mathrm{c}$ is grey, while the sample in Fig. 5a is black, despite the fact that they both are mixtures of additive and black liquor. The grey color presumably resulted from the mechanical mixing of black liquor particles and white additive particles. The color of the sample in Fig. $5 \mathrm{a}$ (with additive) was as black as the color of the dried black 


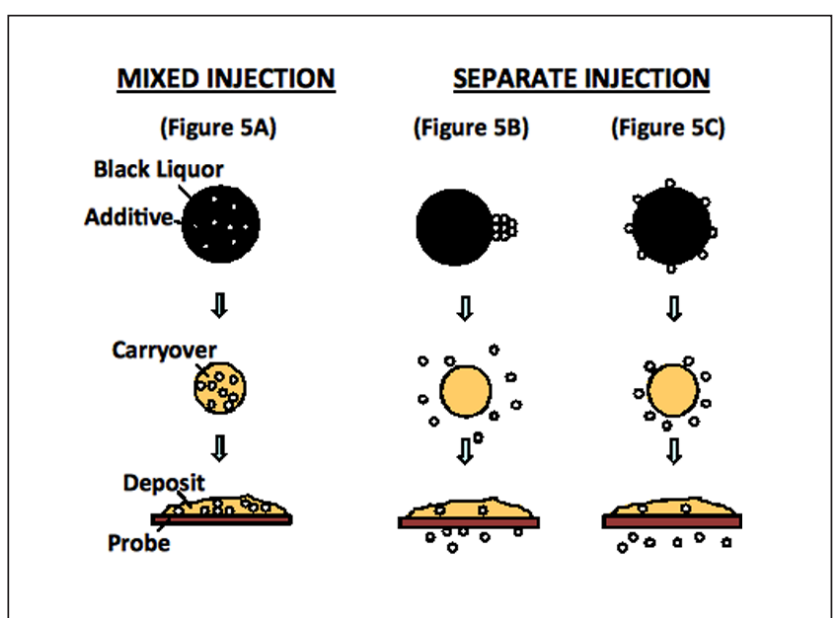

12. Difference in physical conditions of additive particles between mixed injection and separate injection.

liquor powder (with no additive) in Fig. 5b, suggesting that the surface of white $\mathrm{Mg}(\mathrm{OH})_{2}$ additive particles must have been completely covered by black liquor during sample preparation.

Figure 12 schematically shows the difference in physical conditions of $\mathrm{MgO}$ additive particles for the mixed-injection and separate-injection methods used in this study. It explains why the additive capture efficiency was $100 \%$ in the mixedinjection case and only $25 \%$ in the separate-injection case.

\section{FIELD STUDY}

A field study was performed in a recovery boiler where $\mathrm{MgO}$ based additive has been used for many years due to the severe fouling problem in the superheater and generating bank regions. The objective was to determine whether the additive could form a coating layer on the tube surface, how thick the layer could possibly be, and whether the additive could help minimize deposit buildup. This information is important for determining how effectively the additive can be delivered to

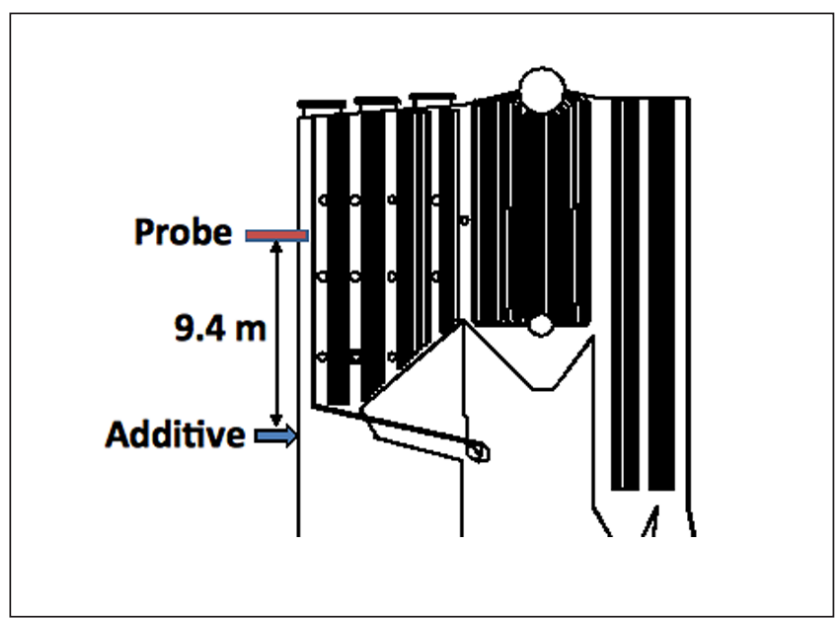

13. Locations of additive injection ports and deposit probe in the recovery boiler. the tube surface and how its use may improve deposit properties and make deposits easy to remove.

The boiler was burning 1800 tons of black liquor dry solids per day. The additive was in the form of $\mathrm{Mg}(\mathrm{OH})_{2}$ and water slurry at $64 \%$ dry solids. It was sprayed into the boiler through six injection ports near the bullnose (Fig. 13): two on the front wall, two on the right wall, and two on the left wall. The additive injection rate was $660 \mathrm{~kg} / \mathrm{day}$, which was equivalent to $0.00037 \mathrm{~kg}$ of additive slurry per kg of black liquor dry solids fired in the boiler.

\section{Test procedures}

The tests were performed over 2 days in summer 2010. During the test period, the boiler was firing softwood black liquor at its full firing capacity. A steel probe, $21 \mathrm{~mm}$ in outside diameter $\mathrm{x} 4.6 \mathrm{~m}$ in length, was inserted $1.8 \mathrm{~m}$ into the boiler through two access ports (left and right) on the front wall of the boiler. The vertical distance between the access ports and the additive injection ports was $9.4 \mathrm{~m}$. Two tests were performed on each day with additive-on and additive-off modes. During the additive-on mode, the additive slurry was injected into the boiler at the normal rate. During the additive-off mode, no additive was injected.

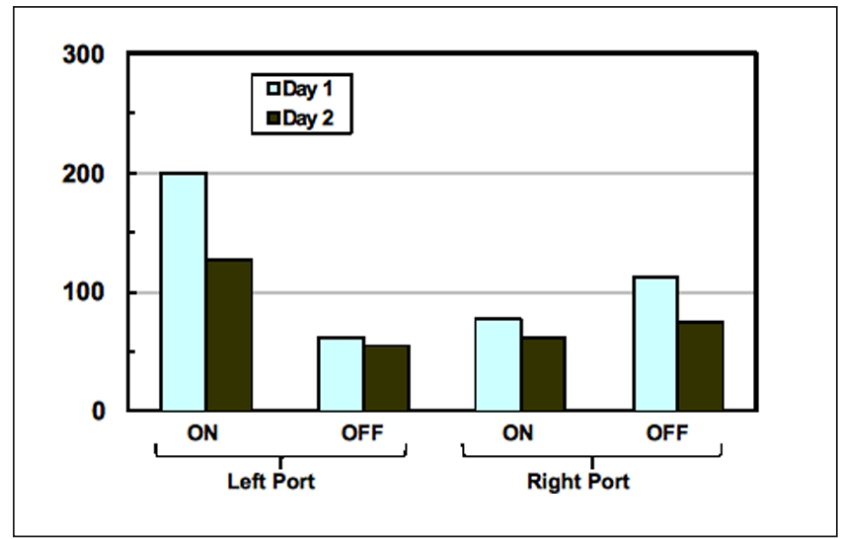

14. Deposit accumulation on the probe at left and right access ports (ON=additive-on mode; OFF=additive-off mode).

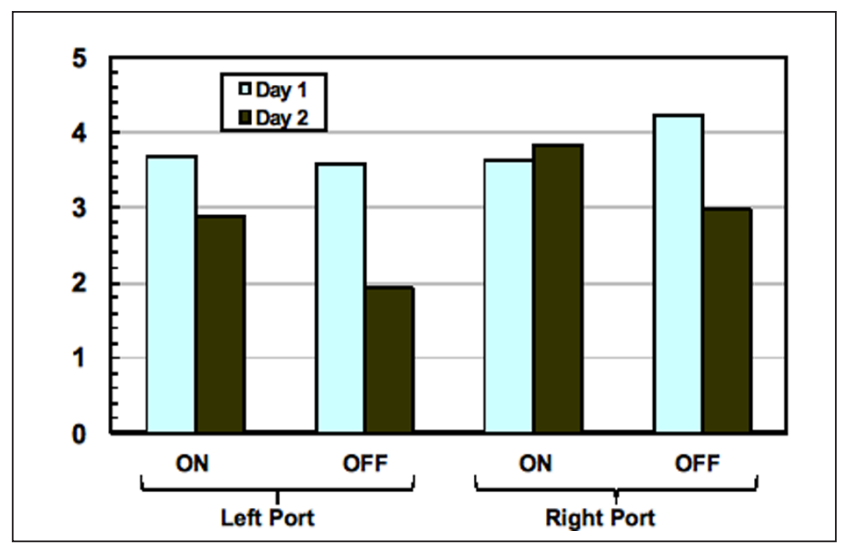

15. $\mathrm{Mg} / \mathrm{Na}$ mass ratios of deposits collected on the probe at left and right access ports $(\mathrm{ON}=$ additive-on mode; OFF=additive-off mode). 


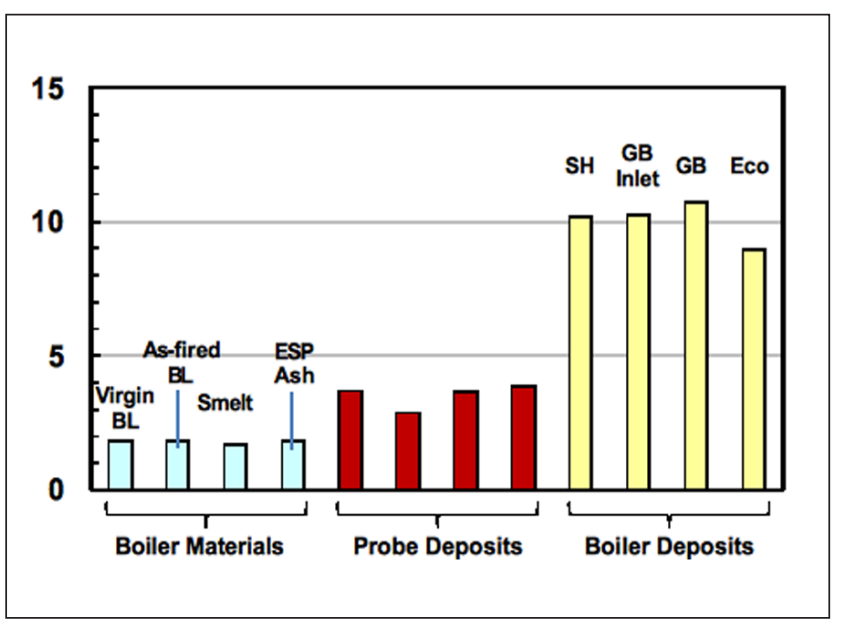

\section{Comparison of $\mathrm{Mg} / \mathrm{Na}$ mass ratios of various field samples.}

The probe was not air-cooled. It was inserted into the boiler for $1 \mathrm{~min}$, removed, and left to cool outside the boiler. After a visual inspection for any indication of additive coating, the deposits on the windward side of the probe were scraped off, weighed, and preserved in well-shielded plastic bags for chemical analysis. The probe surface was cleaned for the next test.

\section{Test results}

Figure 14 shows the amounts of deposits on the probe collected during additive-on and additive-off modes on Day 1 and Day 2. At the right access port, the amount of deposits collected during additive-on mode was smaller than that during additive-off mode for both days, implying that the additive helped minimize deposit formation. At the left access port, however, the result was opposite. The amount the deposits collected during additive-on mode was significantly more than that during additive-off mode, indicating that the additive had an adverse effect on deposition. These conflicting results suggest that the effect of additive on deposition is inconclusive.

Figure 15 shows the $\mathrm{Mg} / \mathrm{Na}$ mass ratio in the deposits. Three of the tests showed a higher $\mathrm{Mg} / \mathrm{Na}$ mass ratio during additive-on mode than during additive-off mode, as expected. However, the test at the right access port on Day 1 showed an unexpected result: the $\mathrm{Mg} / \mathrm{Na}$ mass ratio in the deposits during additive-on mode was lower than that during additiveoff mode.

The difference between the $\mathrm{Mg} / \mathrm{Na}$ mass ratio during additive-on mode and that during additive-off mode was used to estimate how effectively the additive was captured by the deposit. Excluding the anomaly of the result obtained on Day 1 at the right access port, the additive capture efficiency averaged about $19 \%$, varying from $1 \%$ to $33 \%$. This capture efficiency is close to the $25 \%$ value obtained in laboratory experiments for the separate injection case.

\section{$\mathrm{MgO}$ in long-term deposits}

Samples of long-term deposits at various locations in the recovery boiler were collected during the maintenance outage of the boiler in December 2010. Figure 16 shows the $\mathrm{Mg} / \mathrm{Na}$ mass ratios of these samples, along with those of virgin black liquor, as-fired black liquor, smelt, precipitator ash, and 1-min probe deposits obtained in this study.

Virgin black liquor, as-fired black liquor, smelt, and precipitator ash all had a similar $\mathrm{Mg} / \mathrm{Na}$ mass ratio of about 0.0018 , which was roughly one-half of that of probe deposits and one-fifth that of boiler deposits. The higher $\mathrm{Mg} / \mathrm{Na}$ mass ratio of the deposits compared to that of boiler materials implies that some of the $\mathrm{MgO}$ additive injected into the boiler was captured by the deposits.

$\mathrm{The} \mathrm{Mg} / \mathrm{Na}$ mass ratio of probe deposits was only one-third of that of boiler deposits, due presumably to the combination of the following two main reasons:

1. Probe deposits are much less massive and have a smoother surface than boiler deposits. It is, therefore, more difficult for probe deposits to capture additive particles than boiler deposits, resulting in a lower Mg content.

2. The deposition rate at the location where the probe was used (Fig. 13) was much higher than that at the locations downstream where boiler deposits were collected due to the higher flue gas temperature and more carryover particles. More carryover deposition means a higher $\mathrm{Na}$ content.

\section{IMPLICATIONS}

Results of laboratory experiments in this study show the following:

- While MgO additive has little effect on the amount of deposits collected on the air-cooled probe, it may make deposits easy to remove if a coating layer thicker than $30 \mu \mathrm{m}$ can be applied on the probe surface.

- Mixing the additive with black liquor and burning the mixture has a slight adverse effect on deposit buildup, but has a small positive effect on deposit removal.

- Injecting the additive and black liquor separately has no significant effect on both deposition and removal.

These results imply that $\mathrm{MgO}$ additive does not work, unless it can be made to form a thin coating layer on the tube surface. While the coating layer can be made easily in the laboratory, it is not certain whether the layer can be produced in an operating recovery boiler. Visual inspections of probe deposits obtained from both laboratory and field tests showed no evidence of such a coating layer present in the deposits.

Also of note, $\mathrm{MgO}$ melts at a very high temperature $\left(\sim 2900^{\circ} \mathrm{C}\right)$ and does not react with deposits at temperatures prevailing in the recovery boiler. Magnesium oxide particles should, therefore, not be sticky at all. Because they are much 
smaller than carryover particles, they tend to follow the flue gas stream without depositing on the tube surface. As schematically illustrated in Fig. 12, with a large number of carryover particles always surrounding them, $\mathrm{MgO}$ particles are not left alone to form a coating layer on a tube/deposit surface. They are likely to be absorbed by sticky deposits, or be trapped in rough/porous deposit surfaces, and be quickly buried within the deposits.

The $\mathrm{Mg} / \mathrm{Na}$ mass ratio of probe deposits and boiler deposits were 0.0036 and 0.0100 , respectively. These values respectively correspond to $\mathrm{MgO}$ contents of $0.12 \mathrm{wt} \%$ in probe deposits and $0.33 \mathrm{wt} \%$ in boiler deposits, which, according to the results shown in Figs. 6, 7, 9, and 10, are too small to have an impact.

Furthermore, it is important to note that not all the $\mathrm{MgO}$ in the deposits originated from additive; some must have also come from wood. If the wood used at the mill in this study contained no magnesium (Mg), with the injection rate of $0.00037 \mathrm{~kg}$ of additive slurry per kg of black liquor dry solids, the $\mathrm{Mg} / \mathrm{Na}$ mass ratio of the black liquor would have been 0.0005 , slightly smaller than one-fourth of the measured value, 0.0018 (Fig. 15). This means that the additive, at best, could contribute to about one-fourth of the total $\mathrm{Mg}$ in the black liquor. The remaining three-fourths must have come from wood. For such an Mg balance to be possible, the Mg content of the wood used at the mill must have been about $180 \mathrm{ppm}$ or $0.180 \mathrm{~g} / \mathrm{kg}$ wood, which is the typical $\mathrm{Mg}$ content in softwood. It is, therefore, concluded that a substantial portion of the $0.12-0.33 \mathrm{wt} \% \mathrm{MgO}$ in deposits must have originated from the native $\mathrm{Mg}$ in wood. If this is true, it would make the amount of $\mathrm{MgO}$ derived from the additive even smaller, further undermining the usefulness of the additive.

It is imperative to produce an effective coating layer on

\section{ABOUT THE AUTHORS}

We chose this topic because of a need to understand scientifically how $\mathrm{MgO}$ additives work. This research was complementary to the previous work by our research group. The difference is that in this study, the experiments were systematically carried out both in the laboratory and in the field.

The most difficult aspect of this work was to simulate as closely as possible the deposit formation and removal processes and the additive injection methods in the laboratory. We addressed this challenge by using our entrained flow reactor.

The most interesting finding was that a very thin layer of $\mathrm{MgO}$ additive can facilitate deposit removal. $\mathrm{MgO}$ additives may work only if they can effectively form a thin coating layer on tube surfaces. Since the formation of a thin coating layer on tube surfaces is difficult to achieve, the use of $\mathrm{MgO}$ additives is unlikeIy to help mitigate fouling problems in recovery boilers. Mills may use this information to assess whether it is worthwhile to use additives for controlling fire- tube/deposit surfaces in the boiler in order for an additive treatment to work. With the current industry practice of continuously injecting a small amount of additive, this may not be an easy task, as shown in this study. One possibility for improvement is to periodically inject a large amount of additive into the boiler for a short time while reducing the black liquor firing rate at the same time. During such time, there will be a proportional increase in additive particles and an exponential decrease in carryover particles in the flue gas. The mismatch in the amounts will make the additive less influenced by carryover, allowing it to form an MgO coating layer more readily on the tube/deposit surfaces. Alternatively, as has been done in the past [9], the additive may be injected through a sootblower periodically at locations where mass deposits are present.

\section{CONCLUSIONS}

This study suggests that the MgO additive may work only if it can be made to form a thin coating layer on the tube surface. Because this is difficult to achieve with the conventional method of additive application, it is unlikely that the use of $\mathrm{MgO}$ additives can help mitigate fouling problems in recovery boilers. One possible way to produce an effective additive coating layer is to periodically inject a large amount of additive into the boiler for a short time while reducing the black liquor firing rate at the same time. $\mathbf{J}$

\section{ACKNOWLEDGEMENTS}

This work was conducted as part of the research program Increasing Energy and Chemical Recovery Efficiency in the Kraft Process, jointly supported by the Natural Sciences and Engineering Research Council of Canada (NSERC) and a con-

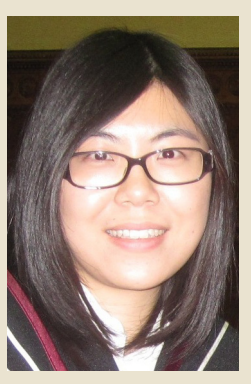

Zhao

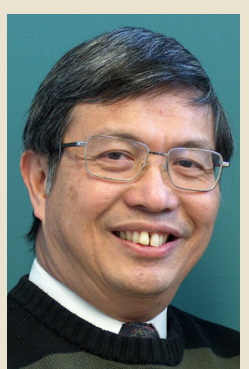

Tran

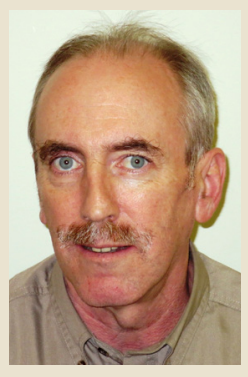

McCabe side fouling in recovery boilers.

This study completes our work on this topic.

Zhao is research associate and Tran is the Frank Dottori professor in the Department of Chemical Engineering \& Applied Chemistry, University of Toronto, Toronto, ON, Canada. McCabe is senior process engineer at Irving Pulp and Paper, Saint John, NB, Canada. Email Tran at honghi.tran@utoronto.ca. 
sortium of the following companies: Andritz, Babcock \& Wilcox, Boise Paper, Carter Holt Harvey, Celulose Nipo-Brasileira, Clyde-Bergemann, DMI Peace River Pulp, Fibria, International Paper, Irving Pulp \& Paper, Metso Power, MeadWestvaco, StoraEnso Research, and Tembec.

\section{LITERATURE CITED}

1. Raak, E., Mineral Impurities in Coal Combustion, Hemisphere Publishing, New York, 1985, pp. 282-311.

2. Radway, J. E., Corrosion and Deposits from Combustion GasesAbstracts and Index, Hemisphere Publishing, New York, 1985, pp. 388-394.

3. Sabol, A.J. and Diep, D.V., "Improve recovery boiler operation with NALKRAFT Program," paper presented at the BLRBAC Committee Meeting, Atlanta, April 1984.

4. Lowe, A.J., McCaffrey, D.J.A., and Richards, D.G., Fuel Process. Technol. 36(1-3): 47(1993).

5. Tran, H.N., TAPPI J. 82(1): 212(1999).

6. Zhao, L., "The effectiveness of magnesium oxide-based additives in mitigating fouling problems in kraft recovery boilers," MSc thesis, University of Toronto, Toronto, ON, 2011.

7. Mao, X., Tran, H.N., and Cormack, D.E., TAPPI J. 84(6): 68(2001).

8. Mao, X., Lee, S., and Tran, H.N., J. Pulp. Pap. Sci. 35(2): 41(2009).

9. Chappell, R.E. and Tester, J.W., "Slurry spray for black liquor boilers," paper presented at the TAPPI Southeastern Section Meeting, Brunswick, GA, USA, May 24, 1963.

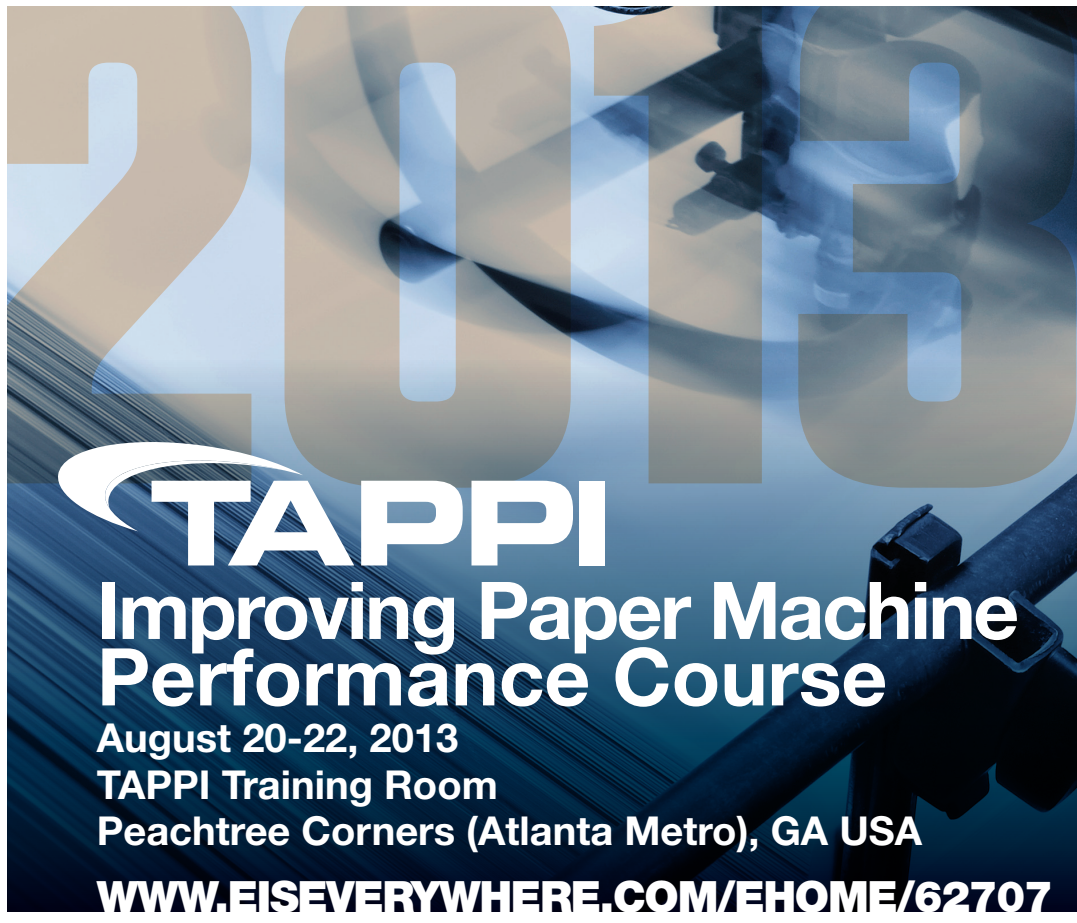

This Intermediate- to Advanced-level course will give you the tools needed to evaluate and benchmark the performance of paper machines against industry standards. By measurements and auditing the performance of the paper machine, you will be able to determine the best course of action for improving the performance and optimizing the efficiency of the paper machine operations.

Learn from four of TAPPI's most experienced instructors, TAPPI Fellows Jim Atkins, Dick Reese, Chuck Klass and Ken Hill.

After attending this course, you should be able to:

- Explain how to establish a paper machine performance audit

- Determine the tools needed to benchmark paper machine operations

- Identify areas of PM performance that are sub-standard

- Utilize the tools from this course to improve paper machine operations and paper quality

\section{Register by July 20 for the best rates! Use your Smart Phone to register now}

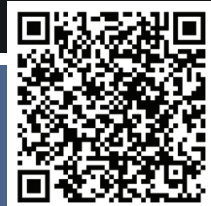

